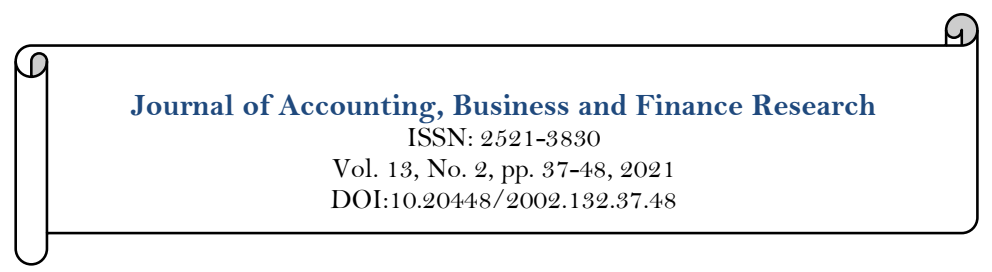

\title{
Enhancing Auditor Independence in Developing Countries in the Context of Globalization - Evidence from Vietnam
}

\section{Le Doan Minh Duc}

School of Accounting, University of Economics, Ho Chi Minh City, Vietnam.

Email:ducldm@ueh.edu.vn

\begin{tabular}{|c|c|}
\hline Abstract & \\
\hline $\begin{array}{l}\text { Globalization brings many opportunities and challenges for } \\
\text { developing countries. So, does globalization create a motivation to } \\
\text { improve the auditing profession's ethics? Independence is one of the } \\
\text { most important components of professional auditing ethics and must } \\
\text { be maintained throughout the audit process. This article takes a new } \\
\text { approach to auditor independence based on globalization in Vietnam } \\
\text { and delivers a full insight into identifying factors that enhance } \\
\text { auditor independence in the international integration process. A } \\
\text { mixed approach to this study is taken based on experimental } \\
\text { methodology. This article uses the archival research and group } \\
\text { discussion methods to analyze and assess the research problems. } \\
\text { Group discussions were conducted with experts and } 280 \text { directors, } \\
\text { auditors, and auditor assistants who work in } 70 \text { auditing firms were } \\
\text { surveyed. The results showed that globalization supports auditors, } \\
\text { audit firms, and professional association to improve auditor } \\
\text { independence. Factors that particularly enhance auditor } \\
\text { independence driven by international integration are knowledge, } \\
\text { technology, competition, management, and monitoring. Based on the } \\
\text { results of the study, it is recommended that auditor independence } \\
\text { should be improved in the context of Vietnam due to the country } \\
\text { being integrated internationally. }\end{array}$ & $\begin{array}{l}\text { Keywords: } \\
\text { Ethics } \\
\text { Auditor independence } \\
\text { International integration } \\
\text { Audit } \\
\text { Professional ethics. } \\
\text { JEL Classification: } \\
\text { M42. } \\
\text { Licensed: } \\
\text { This work is licensed under a } \\
\text { Creative Commons Attribution } 4.0 \\
\text { License. } \\
\text { Publisher: } \\
\text { Scientific Publishing Institute } \\
\text { Received: } 13 \text { September } 2021 \\
\text { Revised: } 18 \text { October } 2021 \\
\text { Accepted: } 2 \text { November } 2021 \\
\text { Published: } 16 \text { November } 2021\end{array}$ \\
\hline
\end{tabular}

Funding: This research is funded by the University of Economics, Ho Chi Minh City, Vietnam.

Competing Interests: The author declares that there are no conflicts of interest regarding the publication of this paper.

\section{Introduction}

Vietnam's recent economic integration has taken clear steps forward. Vietnam became a member of the Association of Southeast Asian Nations (ASEAN) in 1995, joined the Asia-Pacific Economic Cooperation (APEC) in 1998, and signed a bilateral trade agreement with the United States in 2000. The milestone of Vietnam joining the World Trade Organization (WTO) in 2007 marks the comprehensive integration of Vietnam into the world economy (Cling, Razafindrakoto, \& Roubaud, 2011). Along with the efforts to participate in the industrial revolution 4.0, international economic integration has created opportunities for Vietnamese businesses to gain valuable experience in management, modern technology, and advanced production lines in view of production development, trade and services.

The year 1991 marked the first forming period in the history of the independent audit industry in Vietnam. Starting with two established auditing firms, by the end of 2017, Vietnam had 169 auditing firms with nearly 11,000 employees (VACPA, 2008). From here, the independent audit industry in Vietnam has 
developed gradually but strongly compared to other countries in the region in both quality and quantity, meeting the information transparency requirements of society. Auditing activities confirmed the development strategy of the Ministry of Finance of Vietnam and the determination of the Vietnam Association of Certified Public Accountants (VACPA) in implementing a legal environment in accordance with international practices. So far, Vietnam has issued 26 accounting standards and 39 auditing standards in accordance with the International Accounting Standards (IAS) and the International Standards on Auditing (ISA). In these standards, it is worth noting that the issued professional ethics standards are closely related to the independence of auditors. Currently, financial reporting standards are also being implemented with respect to the International Financial Reporting Standards (IFRS). Simultaneously, Vietnamese businesses are stepping up their participation in international auditing firms to improve the quality of audit activities with regard to professional ethics.

Auditor independence is the most important component of professional ethics, which must be maintained throughout the audit process (Previts \& Merino, 1998). In Vietnam, the legal system on auditing is comprehensive and includes legal documents on auditor independence. Auditing companies are applying these regulations to maintain auditor independence during the audit process. However, according to the results of VACPA's annual service quality test, there are still many auditing firms and auditors who have not yet met the requirements in the implementation of the practice regulations related to auditor independence. Although the auditing industry in Vietnam has made remarkable progress, it is still in the early stages of development and there are still many difficulties and limitations to overcome, including the maintenance of auditor independence.

There are many studies on auditor independence with different approaches in each specific context, such as the economic approach (Adams, Krishnan, \& Krishnan, 2021; DeAngelo, 1981; Geiger, North, \& O'Connell, 2005), the behavioral approach (Goldman \& Barlev, 1974; Mustikarini \& Adhariani, 2021), access to risk (Hao, 2021; Johnstone, Warfield, \& Sutton, 2001; Turner, Mock, \& Srivastava, 2002), and the framework approach (Bakar, Rahman, \& Rashid, 2005; Beattie, Brandt, \& Fearnley, 1998; Hoang, Thuong, Minh Duc, \& Hoang Yen, 2019; Ndaba, Harber, \& Maroun, 2021). However, there are no studies on auditor independence from the perspective of international economic integration that promote the enhancement of auditor independence. Research based on this perspective plays an important role in the context of countries with strong international integration, such as Vietnam. In particular, it positively changes the socioeconomic situation as well as production and business activities, including independent audit activities. The objective of this paper is to explore the factors driving the enhancement of auditor independence as a result of the effects of international integration on auditors. The purpose is to help audit firms actively improve their professional capacity, quality and reputation. We have used a mixed research method to answer the following research questions: Q1) What are the factors that promote the independence of auditors in international integration, and $\left.Q^{2}\right)$ How does each of these factors impact auditor independence?

\section{Research Method}

By applying the methodology and the model of Olalere (2012) on empirical research methods in the field of accounting, this article uses a mixed approach that combines qualitative and quantitative methods. Initially, the article reviewed previous studies to identify factors that impact auditor independence. We then took a qualitative approach via one-on-one interviews with a semi-structured questionnaire to cover the concepts of auditor independence motivated by the international integration process. The research sample was selected by experts in Vietnam (data saturation points is 10) (see Appendix 1) and includes leaders of accounting and auditing training programs in high ranking universities, leaders of the VACPA, directors of audit companies, and auditors who have many years of experience. The study expects to discover some new factors that previous studies have not. We assume that the identified factors may affect each other, so the partial least squares structural equation modeling (PLS-SEM) was used as the measurement instrument. The estimated results are determined after performing the tests for the reliability of the data and the suitability of the research model.

\section{Research Overview}

In the process of the audit and issuing the report, the opinion of the auditor must be formulated with independence in mind and independence in appearance (IFAC, 2016). Auditor independence is an important attribute in the auditing of financial statements (Previts \& Merino, 1998). Auditor independence is also a professional ethics attribute that increases the perceived value of audit reports among users because the information contained in audit reports is guaranteed to be professional, objective and unbiased. Previous studies on auditor independence can be grouped into three approaches: (i) auditor characteristics, (ii) environment of the audit company, and (iii) institutional environment (see Figure 1). 


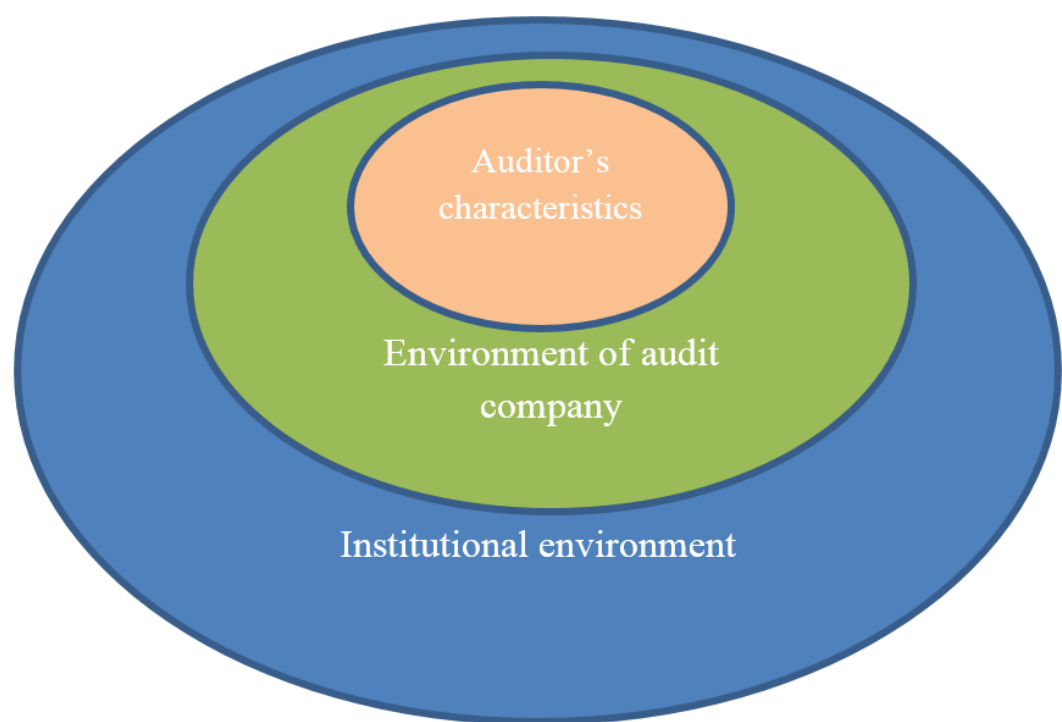

Figure 1. Approaches to auditor independence by group.

\section{(i) The Characteristics of the Auditor}

Auditors begin their career once they have met the ethical and professional standards, gained some work experience and have passed the auditor certificate exam organized by the Ministry of Finance. Annually, auditors must maintain professional expertise as well as professional ethics to continue practicing. Awareness of professional ethics among auditors is formed from the motivations and behaviors learned during the training process (Armstrong, Ketz, \& Owsen, 2003; Ge \& Thomas, 2008; Modarres \& Rafiee, 2011) and are increasingly perceived in the early stages of audit careers (Weeks, Moore, McKinney, \& Longenecker, 1999). The more experienced and older the auditors are, the better ethical awareness they have (Eweje \& Brunton, 2010). In addition, gender can also affect ethical perception (Larkin, 2000), although the actual effect is not clear (Ahson \& Asokan, 2004; Iyer, Raghunandan, \& Rama, 2005).

\section{(ii) Environment of the Audit Company}

The auditor is required to work full-time under a labor contract or capital contribution in an audit company. They must comply with the company's regulations while performing an audit in accordance with the audit process. The audit process begins with the audit contract being signed between the audit firm and the client. The audit fee specified in the contract is paid by the client. This payment is legal and is recognized by the State and Association of Certified Public Accountants (Dogui, Boiral, \& Heras-Saizarbitoria, 2014). Estimating the appropriate audit fee ensures that the audit is conducted carefully and that appropriate steps are taken during the process. However, if the audit fee is too low (DeAngelo, 1981) or too high (Choi, Kim, \& Zang, 2010) it is likely to undermine auditor independence because the auditor may omit some procedures or compromise opinions with clients. This is a risk because financial self-interests can affect the judgment or behavior of auditors.

The working environment may present specific risks to auditor independence. Furthermore, the nature of each signed contract regarding the assigned tasks may differ; it depends on the service provided, which can be an audit service or a non-audit service. Hence, the risks incurred by each client will not be identical. The identification of situations could compromise auditor independence and provide appropriate protective measures, so risks can be eliminated or reduced to acceptable levels. However, this can be based on scientific reasoning. The measures are not easy to implement because the relevant research results are not consistent. Recently, many studies have shown that non-audit services reduce auditor independence, such as Bakar et al. (2005); Robinson (2008); Jenkins and Lowe (2011); Blay and Geiger (2013); Mohamed Ali (2015); Van Liempd, Quick, and Warming-Rasmussen (2019). However, many other studies show that auditor independence is not affected by non-audit services, such as DeFond, Raghunandan, and Subramanyam (2002); Ashbaugh, LaFond, and Mayhew (2003); Ghosh, Kallapur; and Moon (2009).

In addition, during the audit, familiarity may arise due to a long-term or close relationship between the auditor and the client. Recent studies have discovered that this relationship affects the independence of auditors (Adams et al., 2021; Mustikarini \& Adhariani, 2021; Quick \& Warming-Rasmussen, 2015; Ye, Carson, \& Simnett, 2011). However, there are opposing studies that suggest otherwise (Mautz \& Sharaf, 1961). To mitigate these risks, auditors should undertake audit tenure. Presently, there are still many arguments about the necessary length of audit tenure to improve auditor independence. For example, Carcello and Nagy (2004) showed that short audit tenure affects auditor independence, but if prolonged, it minimizes such effects. However, Garcia-Blandon and Argiles (2015) suggested the opposite. In addition, many studies have shown 
that the impact of audit tenure on auditor independence is negligible (Ruiz-Barbadillo, Gomez-Aguilar, \& Carrera, 2009; Wang \& David, 2013).

Moreover, when an auditor is working at an audit firm that classified as large (Chepkorir, 2013), well known (Mohamed Ali, 2015), and has a competitive environment (Bakar et al., 2005; Muthui, Muturi, \& Kabiru, 2014), the awareness and behavior related to auditor independence will be significantly affected.

\section{(iii) Institutional Environment}

Auditors must be supervised by audit firms, professional associations, and the state (IFAC, 2016). Auditors must register to practice on an annual basis. This process grants them a registration certificate which ensures that they have met all the standards for updating knowledge, professional ethics and actual practice time in audit firms (IFAC, 2016). Periodically, the Association of Certified Public Accountants and the State Securities Commission inspect the audit quality and impose sanctions for violations (Kaka, 2021). Therefore, regulations, supervision and control are expected to increase auditor independence.

In addition, auditors form opinions based on the conformity of the collected evidence with the required auditing/accounting standards. Vietnam's accounting/auditing standards are changing positively, step-bystep, in harmony with the world. Therefore, the regulation changes will further enhance auditor independence to ensure audit quality and meet social expectations.

The three main research approaches to auditor independence mentioned above are considered in the context of auditing activities in countries, such as Vietnam, which are gradually moving closer to international practices in a process of strong global integration. However, there are no studies that focus on the impact of the integration process on auditor independence. This research takes a new approach that is suitable in the current context to assess and identify opportunities to improve auditor independence to enhance audit capacity and audit quality. Therefore, we study the factors that promote the independence of auditors from the impact of the international integration process (see Figure 2).

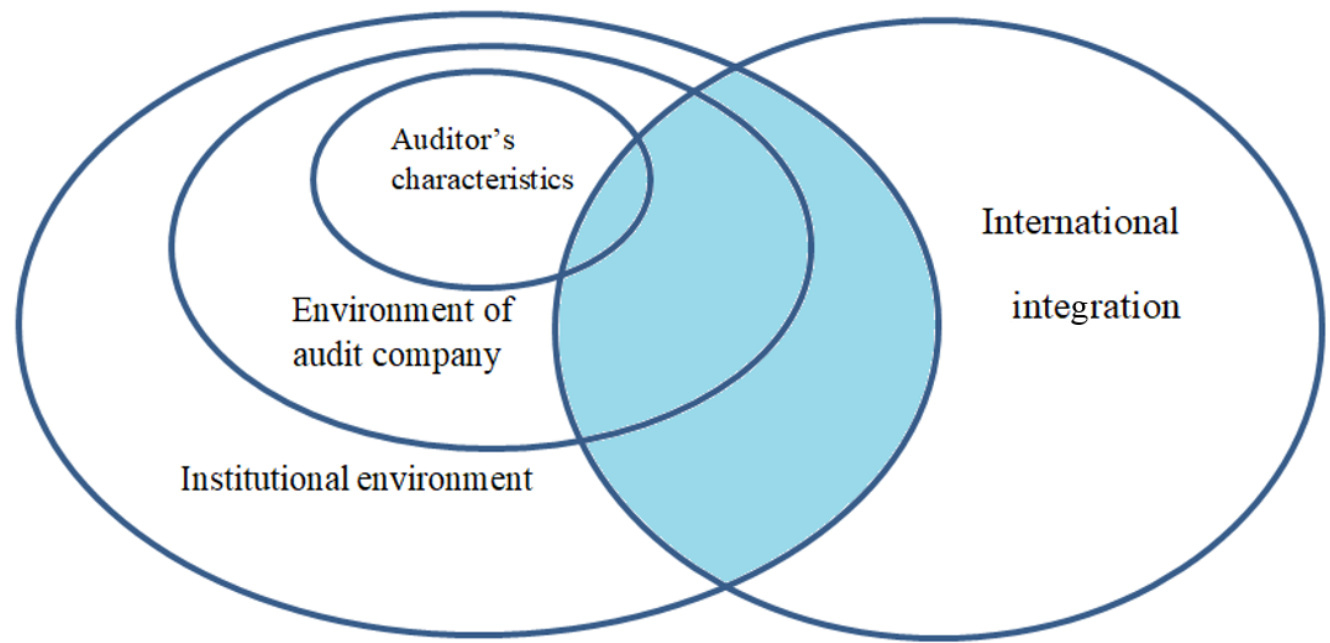

Figure 2. Approach to factors promoting auditor independence from international integration.

\section{Research Results}

\subsection{Qualitative Research Results and the Identification of the Research Model}

The reliability of the qualitative research results is confirmed through a one-on-one interview process with clear evaluation criteria. Firstly, the theory has been built into communicability through the development of an open questionnaire based on a clear and meaningful research topic. Thereafter, the discussion process is continually recorded in transcripts until the research concept achieves a certain level of coherence to form a theory. Next, the data was analyzed according to the appropriate steps (Corbin \& Strauss, 2015) - (i) data categorization and cleansing: initial analysis, create records, import and store information; (ii) analysis and presentation of information: encoding data, finding case studies, labeling groups, developing data systems, and showing relationships between groups; (iii) conclusion and verification of information and synthesizing opinions: preparation of reports and verification of the information. The results of steps (i) and (ii) help to determine the approach to the research on auditor independence in the context of international integration and to fully identify the concepts that promote the enhancement of auditor independence from the international integration process. Step (iii) aims to verify and identify a set of factors affecting auditor independence, which helps to answer the first research question $(\mathrm{Q} 1)$. As a result, we have identified the transparency of the theory in terms of defining concepts that enhance auditor independence from the impact of the international economic integration process (see Appendix 3). 


\subsection{Test Results}

\subsubsection{Research Model and Scale}

With the concepts extracted from the expert group discussion (see Appendix 3), we define each concept as a factor that influences auditor independence driven by the international integration process. We developed a research model (see Figure 3) and a scale design (see Appendix 2) to collect data, and the statistics were analyzed using partial least squares structural equation modeling (PLS-SEM) to answer the second research question $\left(\mathrm{Q}^{2}\right)$.

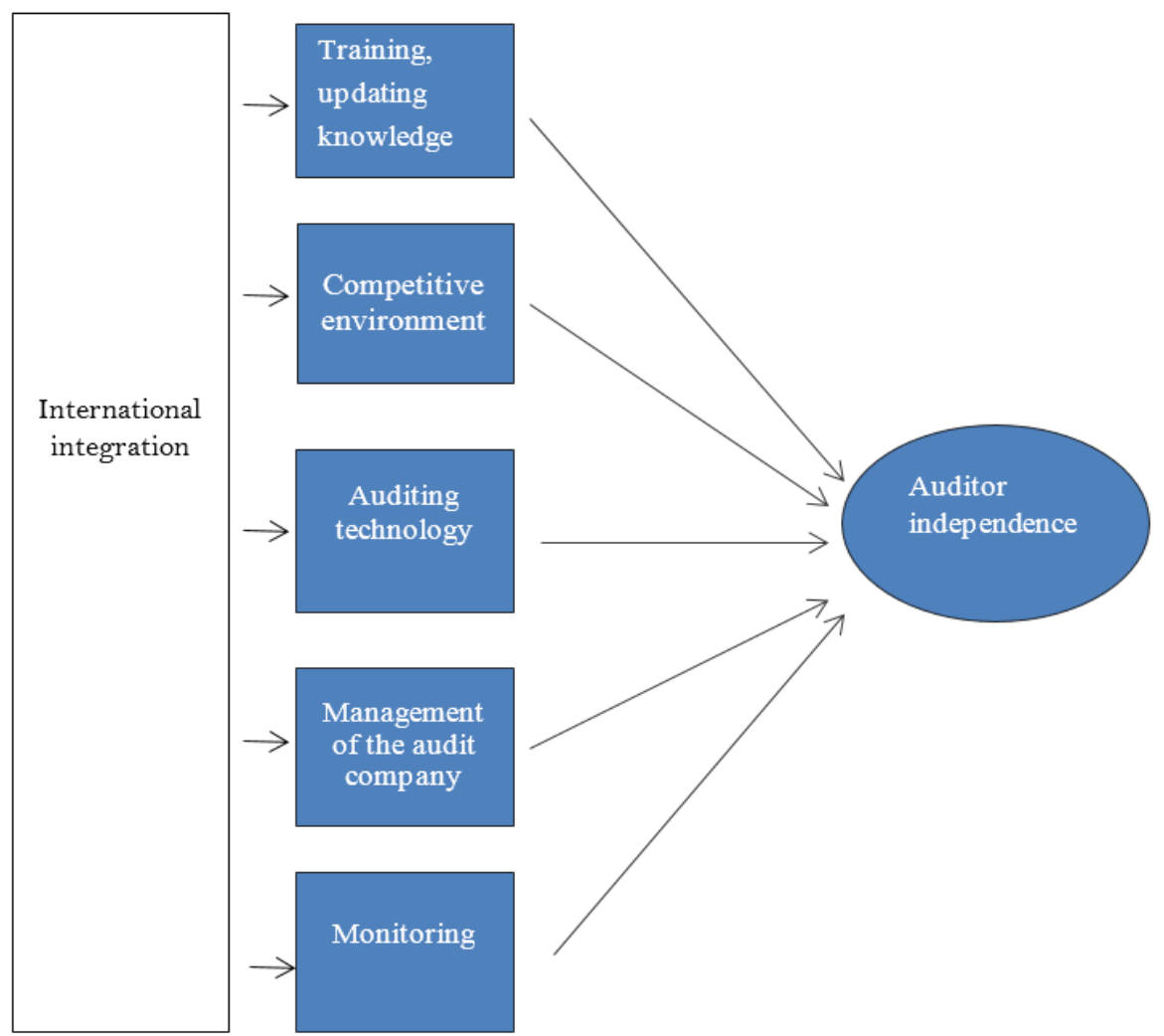

Figure 3. Research model.

The variables in the proposed model are detailed in Table 1.

\begin{tabular}{l|l}
\multicolumn{2}{c}{ Table 1. The variables in the proposed model. } \\
\hline Concept & Variable \\
\hline Auditor independence & Independence \\
\hline Training, updating knowledge & Knowledge \\
\hline Auditing technology & Technology \\
\hline Competitive environment & Competition \\
\hline Management of the audit company & Management \\
\hline Supervision and monitoring & Monitoring \\
\hline
\end{tabular}

\subsubsection{Research Hypotheses}

To start the testing process, hypotheses were formed regarding the impact of each factor on auditor independence.

\section{(i) Training and Updating Knowledge}

Auditors should have the appropriate training and skills. Moreover, in the context of economic integration, there are many new professions and special transactions. Therefore, auditors must gain industryspecific expertise (Gul, Fung, \& Jaggi, 2009) to ensure professional judgments and opinions. Auditors must also keep up to date with new relevant knowledge from universities and auditing firms. Therefore, the following hypothesis is put forward:

H1: Training and updating knowledge increase the independence of auditors. 


\section{(ii) Competitive Environment}

Independent auditors are registered to practice and work full-time at an auditing firm. Therefore, the environment of auditing firms will have an impact on auditor independence. In a highly competitive operating environment, the risk of auditor independence is affected (Bakar et al., 2005; Muthui et al., 2014). However, in the context of international integration, the auditors themselves and the auditing firms must improve the quality and reputation to ensure auditor independence. Therefore, the second hypothesis is as follows:

H2: The competitive environment increases auditor independence.

\section{(iii) Auditing Technology}

Auditors may be supported by computer-based audit tools and techniques in the following forms: electronic working papers, professional word processors, spreadsheets, statistical analysis software and computer programs (Braun \& Davis, 2003). The use of technology stems from behavioral intent (Davis, 1989). Auditors use technology when it offers clear benefits and is easy to use. From there, auditors can also analyze and verify data directly with a variety of databases and software (Braun \& Davis, 2003; Debreceny, Lee, Neo, \& Toh, 2005). As a result, they can improve job performance (Venkatesh, Morris, Davis, \& Davis, 2003) and audit quality and provide objective judgments, thereby improving auditor independence. The third hypothesis posits that:

H3: Auditing technology increases auditor independence.

\section{(iv) Management of the Audit Company}

Management involves the concurrent and effective application of principles related to planning, organizational, directional and control functions. Management exploits physical, financial, human, and information resources to achieve organizational goals (Cadbury, 1992) by following statutory and social practices. In auditing firms, managers use the division of labor and the audit, review and quality control processes to ensure independence and quality. These activities must be consistent with the philosophy and goals of the company and be compliant with professional ethics. An auditing firm that operates under wellperforming management will increase the awareness of professional ethics (Minh, Thi, Hoang, Hoang, \& Hung, 2019) and raise the audit quality (Bahrawe, Haron, \& Hasan, 2016). Therefore, the article assumes: H4: A high level of management in the auditing firm will increase the awareness of auditor independence.

\section{(v) Monitoring}

Association of Certified Public Accountants conducts quality reviews of auditors and auditing firms on an annual basis. The results reflect the audit firm's classification and whether the auditors are qualified. These activities maintain professional ethics, audit quality and reputation. Through the reviews, the Association of Certified Public Accountants assesses the current situations to improve the audit quality to a regional level in the context of international integration. Moreover, the auditing firms also improve the inspection and review of the audits that they carry out. They ensure that the professional ethics of auditors follow international practice guidelines and the requirements of international auditing firms when they become a member. Therefore, the supervision and control of the Association of Certified Public Accountants and the auditing firm can increase auditor independence (Minh et al., 2019).

H5: Examinations by the Association of Certified Public Accountants and auditing firms increase auditor independence.

\subsubsection{Tests of the Reliability and Appropriateness of the Model}

A sample of 280 observations comprising audit company directors, auditors, and auditor assistants practicing at Vietnamese auditing firms (see Table 2). All the respondents have bachelor's degrees or higher (university: $73.9 \%$, postgraduate: $26.1 \%$ ). They meet the statutory criteria and the minimum number of years working in the profession (five years or more $(75.4 \%)$ ). Gender is relatively balanced and consistent with the characteristics of the audit profession.

Table 2. Statistics of observations.

\begin{tabular}{l|c|c}
\hline Observation & Frequency & Percent \\
\hline Education level & 280 & 100.0 \\
\hline University & 207 & 73.9 \\
\hline Postgraduate & 73 & 26.1 \\
\hline Working period & 280 & 100 \\
\hline Less than 5 years & 69 & 24.6 \\
\hline 5-10 Years & 111 & 39.6 \\
\hline 10-15 Years & 66 & 23.6 \\
\hline Over 15 Years & 34 & 12.1 \\
\hline Gender & 280 & 100 \\
\hline Male & 151 & 53.9 \\
\hline Female & 129 & 46.1 \\
\hline
\end{tabular}


Next, the appropriateness of the estimates is evaluated through Cronbach's Alpha coefficients. Cronbach's Alpha reflects the coefficient that evaluates the reliability of the scale. Estimates have good confidence when Cronbach's Alpha values are between 0.7 and 1.0. At the same time, the observed variables used in the analysis have corrected item-total correlation coefficients of 0.3 or more (Nunnally \& Bernstein, 1994). From the results, the Cronbach's Alpha values in Table 3 show that the estimates are consistent and reliable.

Table 3. Summary of measurement results.

\begin{tabular}{|c|c|c|c|}
\hline Variable group & Cronbach's alpha & Variable & Corrected item-total correlation \\
\hline \multirow{4}{*}{ Knowledge } & \multirow{4}{*}{0.716} & Knowledge 1 & 0.741 \\
\hline & & Knowledge 2 & 0.597 \\
\hline & & Knowledge 3 & 0.563 \\
\hline & & Knowledge 4 & 0.160 \\
\hline \multirow{3}{*}{ Technology } & \multirow{3}{*}{0.932} & Technology 1 & 0.925 \\
\hline & & Technology 2 & 0.869 \\
\hline & & Technology 3 & 0.789 \\
\hline \multirow{3}{*}{ Competition } & \multirow{3}{*}{0.894} & Competition 1 & 0.925 \\
\hline & & Competition 2 & 0.869 \\
\hline & & Competition 3 & 0.789 \\
\hline \multirow{4}{*}{ Management } & \multirow{4}{*}{0.850} & Management 1 & 0.750 \\
\hline & & Management 2 & 0.632 \\
\hline & & Management 3 & 0.628 \\
\hline & & Management 4 & 0.768 \\
\hline \multirow{3}{*}{ Monitoring } & \multirow{3}{*}{0.718} & Monitoring 1 & 0.578 \\
\hline & & Monitoring 2 & 0.656 \\
\hline & & Monitoring 3 & 0.397 \\
\hline \multirow{3}{*}{ Independence } & \multirow{3}{*}{0.880} & Independence 1 & 0.742 \\
\hline & & Independence 2 & 0.800 \\
\hline & & Independence 3 & 0.763 \\
\hline
\end{tabular}

However, the article did not continue to use Knowledge 4 in further steps because of a corrected itemtotal correlation less than 0.3.

An exploratory factor analysis (EFA) was then carried out on the variables. We examined the convergence of observational variables and found that the Kaiser-Meyer-Olkin (KMO) coefficient is [0.5; 1] with a Sig. $=0.000<0.5$ (see Table 4). So, the independent factor and dependent factor analyses are appropriate.

Table 4. KMO and Bartlett's test.

\begin{tabular}{l|l|cr}
\hline & \multicolumn{2}{c}{$\begin{array}{c}\text { Dependent } \\
\text { variable }\end{array}$} & $\begin{array}{c}\text { Independent } \\
\text { variables }\end{array}$ \\
\hline \multicolumn{2}{l}{ Kaiser-Meyer-Olkin measure of sampling adequacy } & 0.738 & 0.703 \\
\hline Bartlett's test of sphericity & Approx. chi-square & 449.081 & 2649.952 \\
\cline { 2 - 4 } & Df & 3 & 120 \\
\cline { 2 - 4 } & Sig. & 0.000 & 0.000 \\
\hline
\end{tabular}

To assess the model's suitability for market data, the chi-square/df, the Tucker-Lewis index (TLI), the Confirmatory Fit Index (CFI), and the root mean square error of approximation (RMSEA) were used to determine the suitability of the model compared to the population. Researchers often distinguish two cases. If the chi-square $/ \mathrm{df}<5$, with a sample size of $>200$; or the chi-square $/ \mathrm{df}<3$ when the sample size is $<200$, the model is considered good. In this study, the sample size is $280(\mathrm{~N}>200)$. Therefore, if the model shows a chisquare/df $<5$ (also known as $\mathrm{cmin} / \mathrm{df}<5$ ), a TLI and CFI $\geq 0.9$, and an RMSEA $\leq 0.08$, it is considered suitable. The results of the CFA presented in Table 5 show that $\mathrm{CMIN} / \mathrm{DF}=1.976<5$, CFI $=0.956>0.9$, and RMSEA $=0.059<0.08$; therefore, the model is appropriate.

Table 5. Analysis of confirmatory factor analysis (CFA).

\begin{tabular}{l|c|c|c}
\hline Model & CMIN/DF & CFI & RMSEA \\
\hline Default model & 1.976 & 0.956 & 0.059 \\
\hline Saturated model & & 1.000 & \\
\hline Independence model & 18.965 & 0.000 & 0.254 \\
\hline
\end{tabular}

From the test results, the research model is confirmed to be reliable. The regression model is estimated as follows in Table 6. 
Table 6. Summary of estimation.

\begin{tabular}{|c|c|c|}
\hline Relationship & $\begin{array}{l}\text { Correlation of the variables in the } \\
\text { standardized estimation model }\end{array}$ & $\begin{array}{l}\text { Impact } \\
\text { coefficient }\end{array}$ \\
\hline Auditing technology-Auditor independence & Technology ----> Independence & +0.033 \\
\hline $\begin{array}{l}\text { Knowledge updating and training-Auditor } \\
\text { independence }\end{array}$ & Knowledge ----> Independence & +0.023 \\
\hline $\begin{array}{l}\text { Management of auditing firms-Audit } \\
\text { independence }\end{array}$ & Management ----> Independence & +0.017 \\
\hline $\begin{array}{l}\text { Monitoring and supervision-Auditor } \\
\text { independence }\end{array}$ & Monitoring ----> Independence & +0.015 \\
\hline $\begin{array}{l}\text { Competition environment-Auditor } \\
\text { independence }\end{array}$ & Competition ----> Independence & -0.025 \\
\hline
\end{tabular}

The above table shows that the factors promoting auditor independence according to the level are auditing technology; training and updating knowledge; management of auditing firms; and monitoring and supervision. Meanwhile, the competitive environment reduces auditor independence. Assuming that other factors are constant, the direction of the impact of the factors on auditor independence is consistent with the original hypotheses H1, H2, H4, and H5. However, hypothesis H3 is not appropriate because of its negative correlation with the original. In the short term, the study shows that competitive pressure creates negative situations, such as reducing audit fees and reducing some audit procedures to lower costs. However, in the long term, competition can increase auditor independence by enhancing audit quality.

\section{Implications}

Vietnam is a developing country and has many different characteristics of developed countries. Therefore, research on auditor independence in Vietnam has many differences compared to studies in other countries. In recent years, Vietnam is included in the strong internationalization trend around the world. The internationalization process is a motivation that influences and changes auditor independence. Therefore, the empirical evidence in Vietnam reflects a global shift in the audit industry and the associated professional ethics. The following implications are useful not only for Vietnam but also for other countries.

International integration is an inevitable trend taking place in most countries around the world. Therefore, to survive the new trend, every individual and organization in the audit industry need to have a heightened awareness to actively seize new opportunities, new knowledge and new technology. At the same time, organizations must proactively improve their reputation and audit quality in the context of global competition. To enhance auditor independence, this article recommends the following:

\section{(i) Knowledge and Training}

Universities should improve training programs that specialize in auditing and focus on professional ethical standards consistent with international practices. Universities should continue to support soft skills, such as foreign languages and audit techniques. The Association of Certified Public Accountants should constantly renew the training and certification of auditors. The Vietnamese auditor certificate should be improved in order to be recognized by other countries in the region. Auditors themselves must actively sharpen their professional skills and foreign languages in compliance with international standards so that they can participate in highly-qualified work in the integration trend and the fourth industrial revolution.

\section{(ii) Technology}

Auditors must actively improve their audit ability according to audit processes and techniques that match the trends from the research results. In addition, using modern audit techniques of international auditing firms and improving the manipulation of data for auditing work is very important. Auditing firms should build an audit information system in the context of current information technology development, which combines human factors, processes, auditing procedures, data (mining, analysis, storage), engineering and technology into a complete system.

\section{(iii) Competition}

To increase competitiveness, auditing firms should join members of international auditing firms to absorb modern audit technology, techniques and procedures. In addition, on the part of the audited client, it is also necessary to consider establishing an audit committee to select an appropriate auditing firm and supervise all stages of the audit.

\section{(iv) Management of the Auditing Firm}

Auditing firms should (i) build an effective and advanced audit process; (ii) implement a quality control system; (iii) conduct internal audits that focus on the effectiveness of work and compliance with professional 
ethics and regulations; (iv) improve management processes, such as audit, recruitment and training processes. The Association of Certified Public Accountants already improves the management of auditing firms through its annual quality tests and, where appropriate, proposes improvements for weak management systems.

\section{(v) Monitoring}

The Association of Certified Public Accountants should set up a committee or a department with an independent control function to regularly control the observance of professional ethics. In addition, the government should (i) continue to improve the legal framework on independent audits based on inheritance and customization from international auditing/accounting standards; (ii) build a framework of audit fees to reduce unfair competition among auditing firms; (iii) perfect the framework for imposing sanctions for violations in the audit field; and (iv) strengthen the quality control of audit firms and auditors periodically and irregularly.

\section{References}

Adams, T., Krishnan, J., \& Krishnan, J. (2021). Client influence and auditor independence revisited: Evidence from auditor resignations. Journal of Accounting and Public Policy, 4O(5), 106846. https://doi.org/10.1016/j.jaccpubpol.2021.106846

Ahson, U., \& Asokan, A. (2004). Dimensions of pressures faced by auditors and its impact on auditors' independence. A comparative study of the USA and Australia. Managerial Auditing Journal, 19(1), 99-116. https://doi.org/10.1108/02686900410509848

Armstrong, M. B., Ketz, J. E., \& Owsen, D. (2003). Ethics education in accounting: Moving toward ethical motivation and ethical behavior. Journal of Accounting Education, 21(1), 1-16. https://doi.org/10.1016/s0748-5751(02)00017-9

Ashbaugh, H., LaFond, R., \& Mayhew, B. W. (2003). Do non-audit services compromise auditor independence? Further evidence. Accounting Review, 78(3), 611-639. https://doi.org/10.2308/accr.2003.78.3.611

Bahrawe, S. H., Haron, H., \& Hasan, A. N. B. (2016). Corporate governance and auditor independence in Saudi Arabia: Literature review and proposed conceptual framework. International Business Research, 9(11), 1-15. https://doi.org/10.5539/ibr.v9n11p1

Bakar, N. B. A., Rahman, A. R. A., \& Rashid, H. M. A. (2005). Factors influencing auditor independence: Malaysian loan officers' perceptions. Managerial Auditing Journal, 20(8), 804-822. https://doi.org/10.1108/02686900510619665

Beattie, V., Brandt, R., \& Fearnley, S. (1998). Auditor independence and the expectations gap: Some evidence of changing user perceptions. Journal of Financial Regulation and Compliance, 6(2), 159-170. https://doi.org/10.1108/eb024966

Beattie, V., Brandt, R., \& Fearnley, S. (1999). Perceptions of auditor independence: U.K. evidence. Journal of International Accounting, Auditing and Taxation, 8(1), 67-107. https://doi.org/10.1016/S106 1-9518(99)00005-1

Behn, B. K., Carcello, J. V., Hermanson, D. R., \& Hermanson, R. H. (1999). Client satisfaction and big 6 audit fees. Contemporary Accounting Research, 16(4), 587-608.

Blay, A. D., \& Geiger, M. A. (2013). Auditor fees and auditor independence: Evidence from going concern reporting decisions. Contemporary Accounting Research, 30(2), 579-606. https://doi.org/10.1111/j.1911-3846.2012.01166.x

Braun, R. L., \& Davis, H. E. (2003). Computer-assisted audit tools and techniques: Analysis and perspectives. Managerial Auditing Journal, 18(9), 725-731. https://doi.org/10.1108/02686900310500488

Cadbury, A. (1992). Report of committee on the financial Aspects of corporate governance. London: Gee.

Carcello, J. V., \& Nagy, A. L. (2004). Audit firm tenure and fraudulent financial reporting. Auditing: A Journal of Practice $\mathcal{E}^{\circ}$ Theory, 23(2), 55-69. https://doi.org/10.2308/aud.2004.23.2.55

Chepkorir, C. (2013). Factors influencing auditor's independence and accountability: A case study of KTDA affiliated tea factories in Bomet and Kericho County, Kenya. Doctoral Dissertation, Thesis.

Choi, J.-H., Kim, J.-B., \& Zang, Y. (2010). Do abnormally high audit fees impair audit quality? Auditing: A Journal of Practice \& Theory, 29(2), 115-140. https://doi.org/10.2308/aud.2010.29.2.115

Cling, J.-P., Razafindrakoto, M., \& Roubaud, F. (2011). The informal economy in Viet Nam. International Labour Organization.

Corbin, J., \& Strauss, A. (2015). Basics of qualitative research: Techniques and procedures for developing grounded theory (4th ed.). Thousand Oaks, CA: Sage Publications, Inc.

Curtis, M. B., \& Payne, E. A. (2014). Modeling voluntary CAAT utilization decisions in auditing. Managerial Auditing Journal, 29(4), 304-326.

Davis, F. D. (1989). Perceived usefulness, perceived ease of use, and user acceptance of information technology. MIS Quarterly, 13(3), 318-340. https://doi.org/10.2307/249008

DeAngelo, L. E. (1981). Auditor independence, 'low balling', and disclosure regulation. Journal of Accounting and Economics, 3(2), 113-127. https://doi.org/10.1016/0165-4101(81)90009-4

Debreceny, R., Lee, S.-L., Neo, W., \& Toh, J. S. (2005). Employing generalized audit software in the financial services sector: Challenges and opportunities. Managerial Auditing Journal, 20(6), 605-618. https://doi.org/10.1108/02686900510606092

DeFond, M. L., Raghunandan, K., \& Subramanyam, K. R. (2002). Do non-audit service fees impair auditor independence? Evidence from going concern audit opinions. Journal of Accounting Research, 40(4), 1247-1274. https://doi.org/10.1111/1475-679x.00088

Dogui, K., Boiral, O., \& Heras-Saizarbitoria, I. (2014). Audit fees and auditor independence: The case of ISO 14001 certification. International Journal of Auditing, 18(1), 14-26. https://doi.org/10.1111/ijau.12008 
Eweje, G., \& Brunton, M. (2010). Ethical perceptions of business students in a New Zealand university: Do gender, age and work experience matter? Business Ethics: A European Review, 19(1), 95-111. https://doi.org/10.1111/j.14678608.2009.01581.x

Fatima, A. T., Kami, 1. M. D. I., \& Zaimah, Z. A. (2014). Measuring Nigerian stakeholders' perceptions of auditor independence: A proposed framework. Asian Social Science, 1O(14), 81-92.

Garcia-Blandon, J., \& Argiles, J. M. (2015). Audit firm tenure and independence: A comprehensive investigation of audit qualifications in Spain. Journal of International Accounting, Auditing and Taxation, 24, 82-93. https://doi.org/10.1016/j.intaccaudtax.2015.02.001

Ge, L., \& Thomas, S. (2008). A cross-cultural comparison of the deliberative reasoning of Canadian and Chinese accounting students. Journal of Business Ethics, 82(1), 189-2 11. https://doi.org/10.1007/s 10551-007-9571-5

Geiger, M. A., North, D. S., \& O'Connell, B. T. (2005). The auditor-to-client revolving door and earnings management. Journal of Accounting, Auditing \& Finance, 20(1), 1-26. https://doi.org/10.1177/0148558x0502000101

Ghosh, A. A., Kallapur, S., \& Moon, D. (2009). Audit and non-audit fees and capital market perceptions of auditor independence. Journal of Accounting and Public Policy, 28(5), 369-385. https://doi.org/10.1016/j.jaccpubpol.2009.07.001

Goldman, A., \& Barlev, B. (1974). The auditor-firm conflict of interests: Its implications for independence. The Accounting Review, 49(4), 707-718.

Gul, F. A., Fung, S. Y. K., \& Jaggi, B. (2009). Earnings quality: Some evidence on the role of auditor tenure and auditors' industry expertise. Journal of Accounting and Economics, 47(3), 265-287. https://doi.org/10.1016/j.jacceco.2009.03.001

Hao, X. (2021). The relationship between non-audit services and auditor independence: Evidence from Chinese listed companies. Proceedings of Business and Economic Studies, 4(1), 1-5. https://doi.org/10.26689/pbes.v4i 1.1860

Hoang, T. N., Thuong, T. M., Minh Duc, L. D., \& Hoang Yen, N. T. (2019). Enhancing independence of local auditing services by profiting from experiences of the Big4 group (KPMG, Deloitte, PWC E\&Y) operating in Vietnam market. Cogent Business \&ٔ Management, 6(1), 1605702. https://doi.org/10.1080/2331 1975.2019.1605702

IFAC. (2016). Handbook of the code of ethics for professional accountants. IFAC.

Iyer, V. M., Raghunandan, K., \& Rama, D. V. (2005). Gender differences in perceptions of accounting firm alumni. Managerial Auditing Journal, 20(5), 449-459. https://doi.org/10.1 108/02686900510598812

Jenkins, J. G., \& Lowe, D. J. (2011). Auditors as advocates for their clients: Perceptions of the auditor-client relationship. Journal of Applied Business Research, 15(2), 73-78. https://doi.org/10.19030/jabr.v 15i2.5680

Johnstone, K. M., Warfield, T. D., \& Sutton, M. H. (2001). Antecedents and consequences of independence risk: Framework for analysis. Accounting Horizons, 15(1), 1-18. https://doi.org/10.2308/acch.2001.15.1.1

Kaka, E. J. (2021). Covid-19 and auditing. Journal of Applied Accounting and Taxation, 6(1), 1-10. https://doi.org/10.30871/jaat.v6i1.2311

Larkin, J. M. (2000). The ability of internal auditors to identify ethical dilemmas. Journal of Business Ethics, 23(4), 401-409.

Mautz, R.K., \& Sharaf, H. H. (1961). The philosophy of auditing. American Accounting Association, 1961, 6.

Minh, D. L. D., Thi, H. Y. N., Hoang, N. T. V., Hoang, T. N., \& Hung, A. D. B. (2019). Enhancing auditors' independence in auditing enterprises in Vietnam. Cogent Economics \& Finance, 7(1), 1602240. https://doi.org/10.1080/23322039.2019.1602240

Modarres, A., \& Rafiee, A. (2011). Influencing factors on the ethical decision making of Iranian accountants. Social Responsibility Journal, 7(1), 136-144. https://doi.org/10.1108/17471111111114594

Mohamed Ali, O. (2015). Factors affecting auditor independence in Tunisia: The perceptions of financial analysts. Finance and Accounting, 3(3), 42-49. https://doi.org/10.11648/j.jfa.20150303.12

Mustikarini, A., \& Adhariani, D. (2021). In auditor we trust: 44 years of research on the auditor-client relationship and future research directions. In Meditari Accountancy Research. https://doi.org/10.1 108/MEDAR-1 1-2020-1062

Muthui, T., Muturi, W., \& Kabiru, J. (2014). Factors affecting external auditors' independence in discharging their responsibilities: A survey of medium level auditing firms in Nairobi. International Journal of Business and Law Research, 2(4), 22-35.

Ndaba, H., Harber, M., \& Maroun, W. (2021). Audit quality implications of regulatory change in South Africa. Journal of Accounting in Emerging Economies, 11(3), 477-507. https://doi.org/10.1108/JAEE-1 1-2020-0290

Nunnally, J., \& Bernstein, I. (1994). Psychometric theory (3rd ed. Vol. 3). New York: McGraw-Hill.

Olalere, T. (2012). Methodology in accounting research: A critique of taxonomy. SSRN Electronic Journal. https://doi.org/10.2139/ssrn.1921192

Previts, G. J., \& Merino, B. D. (1998). A history of accountancy in the United States: the cultural significance of accounting. In Choice Reviews Online (Vol. 36). Columbus: Ohio State University Press.

Quick, R., \& Warming-Rasmussen, B. (2015). An experimental analysis of the effects of non-audit services on auditor independence in appearance in the European Union: Evidence from Germany. Journal of International Financial Management \& Accounting, 26(2), 150-187. https://doi.org/10.1111/jifm.12026

Robinson, D. (2008). Auditor independence and auditor-provided tax service: Evidence from going-concern audit opinions prior to bankruptcy filings. Auditing: A Journal of Practice \& Theory, 27(2), 31-54. https://doi.org/10.2308/aud.2008.27.2.31

Ruiz-Barbadillo, E., Gomez-Aguilar, N., \& Carrera, N. (2009). Does mandatory audit firm rotation enhance auditor independence? Evidence from Spain. Auditing: A Journal of Practice \& Theory, 28(1), 113-135. https://doi.org/10.2308/aud.2009.28.1.113

Turner, J. L., Mock, T. J., \& Srivastava, R. P. (2002). A formal model of auditor independence risk. Australian Accounting Review, 12(27), 31-38. https://doi.org/10.1111/j.1835-2561.2002.tb00201.x

VACPA. (2008). Documents of annual meeting. VACPA, 2018.

Van Liempd, D., Quick, R., \& Warming-Rasmussen, B. (2019). Auditor-provided non-audit services: Post-EU-regulation evidence from Denmark. International Journal of Auditing, 23(1), 1-19. https://doi.org/10.1111/ijau.12131 
Venkatesh, V., Morris, M. G., Davis, G. B., \& Davis, F. D. (2003). User acceptance of information technology: Toward a unified view. MIS Quarterly: Management Information Systems, 27(3), 425-478. https://doi.org/10.2307/30036540

Wang, S. W. S., \& David, H. (2013). Auditor Independence in New Zealand: Further evidence on the role of non-audit services. Journal of Accounting and Management Information Systems, 12(2), 235-262. https://doi.org/10.2139/ssrn.2218072

Weeks, W. A., Moore, C. W., McKinney, J. A., \& Longenecker, J. G. (1999). The effects of gender and career stage on ethical judgment. Journal of Business Ethics, 20(4), 301-313. https://doi.org/10.1023/A:1005955501120

Ye, P., Carson, E., \& Simnett, R. (2011). Threats to auditor independence: The impact of relationship and economic bonds. Auditing: A Journal of Practice \& Theory, 30(1), 121-148. https://doi.org/10.2308/aud.201 1.30.1.121

\section{Appendices}

Appendix 1. List of experts participating in a one-on-one interview.

\begin{tabular}{l|l|l|l}
\hline No. & $\begin{array}{l}\text { Expert } \\
\text { (Encrypted) }\end{array}$ & Position and workplace & $\begin{array}{l}\text { Work } \\
\text { experience }\end{array}$ \\
\hline 1 & Expert 1 & Leader, Vietnam association of certified public accountants & 22 years \\
\hline 2 & Expert 2 & Secretary, Vietnam association of certified public accountants & 20 years \\
\hline 3 & Expert 3 & Leader of an audit training program in a university & 25 years \\
\hline 4 & Expert 4 & Leader of an audit training program in a university & 18 years \\
\hline 5 & Expert 5 & Leader of an accounting training program in a university & 15 years \\
\hline 6 & Expert 6 & Director of an audit firm & 19 years \\
\hline 7 & Expert 7 & Director of an audit firm & 17 years \\
\hline 8 & Expert 8 & Auditor & 10 years \\
\hline 9 & Expert 9 & Auditor & 11 years \\
\hline 10 & Expert 10 & Auditor & 11 years \\
\hline
\end{tabular}

Appendix 2. Scale and survey questions.

A five-point Likert scale was used ( $1=$ Strongly disagree; $2=$ Disagree; $3=$ No comment; $4=$ Agree; $5=$ Strongly agree).

\begin{tabular}{|c|c|c|c|}
\hline Concept & $\begin{array}{l}\text { Representative } \\
\text { variable }\end{array}$ & Variable measurement & $\begin{array}{l}\text { The basis } \\
\text { of the scale }\end{array}$ \\
\hline \multicolumn{4}{|c|}{ Training, updating knowledge } \\
\hline \multirow{4}{*}{$\begin{array}{l}\text { Training, } \\
\text { updating } \\
\text { knowledge }\end{array}$} & Knowledge 1 & $\begin{array}{l}\text { Independent auditors regularly self-study to } \\
\text { update and improve their professional } \\
\text { qualifications, professional ethics and auditing } \\
\text { techniques to meet international standards }\end{array}$ & $(*)$ \\
\hline & Knowledge 2 & $\begin{array}{l}\text { The auditing firm regularly organizes courses for } \\
\text { employees on auditing/accounting standards, } \\
\text { professional ethics and auditing techniques based } \\
\text { on international standards }\end{array}$ & $(*)$ \\
\hline & Knowledge 3 & $\begin{array}{l}\text { The Association of Certified Public Accountants } \\
\text { introduces content of auditing accounting } \\
\text { standards, professional ethics and audit } \\
\text { techniques from international standards for } \\
\text { auditors }\end{array}$ & $(*)$ \\
\hline & Knowledge 4 & $\begin{array}{l}\text { Universities regularly update the accounting and } \\
\text { auditing standards, professional ethics and } \\
\text { auditing techniques from international standards } \\
\text { for their specialized training programs in } \\
\text { accounting, auditing and finance }\end{array}$ & $(*)$ \\
\hline \multirow{3}{*}{$\begin{array}{l}\text { Auditing } \\
\text { technology }\end{array}$} & Technology 1 & $\begin{array}{l}\text { Auditing technology increases the performance of } \\
\text { auditors }\end{array}$ & \multirow{3}{*}{$\begin{array}{l}\text { Curtis and } \\
\text { Payne } \\
(2014)\end{array}$} \\
\hline & Technology 2 & $\begin{array}{l}\text { Auditing technology gives auditors many } \\
\text { favorable promotion opportunities }\end{array}$ & \\
\hline & Technology 3 & Auditing technology increases audit quality & \\
\hline \multirow{3}{*}{ Competition } & Competition 1 & $\begin{array}{l}\text { The competition between auditors improves audit } \\
\text { quality }\end{array}$ & \multirow{3}{*}{$(*)$} \\
\hline & Competition 2 & $\begin{array}{l}\text { The competition between auditing companies } \\
\text { improves audit quality }\end{array}$ & \\
\hline & Competition 3 & $\begin{array}{l}\text { The Association of Certified Public Accountants } \\
\text { improves the quality of its members }\end{array}$ & \\
\hline Management & Management 1 & The auditing firm improves the auditing process & $(*)$ \\
\hline
\end{tabular}




\begin{tabular}{|c|c|c|c|c|c|}
\hline & Management 2 & \multicolumn{3}{|c|}{$\begin{array}{l}\text { The auditing firm improves control of } \\
\text { professional ethics }\end{array}$} & $(*)$ \\
\hline & Management 3 & \multicolumn{3}{|c|}{$\begin{array}{l}\text { The Association of Certified Public Accountants } \\
\text { improves the quality review process }\end{array}$} & $(*)$ \\
\hline & Management 4 & \multicolumn{3}{|c|}{$\begin{array}{l}\text { The Association of Certified Public Accountants } \\
\text { consults with and promulgates } \\
\text { auditing/accounting standards and professional } \\
\text { ethics }\end{array}$} & $(*)$ \\
\hline \multirow{3}{*}{ Monitoring } & Monitoring 1 & \multicolumn{3}{|c|}{ Control of the audit company } & $(*)$ \\
\hline & Monitoring 2 & \multicolumn{3}{|c|}{ Supervision of professional organizations } & $(*)$ \\
\hline & Monitoring 3 & \multicolumn{3}{|c|}{ Quality audit review } & $(*)$ \\
\hline \multicolumn{6}{|c|}{ Ethical awareness of independent auditors } \\
\hline \multirow[b]{3}{*}{$\begin{array}{l}\text { Auditor } \\
\text { independence }\end{array}$} & Independence 1 & \multicolumn{3}{|c|}{$\begin{array}{l}\text { Auditors do not take any actions that harm } \\
\text { auditor independence during the audit process }\end{array}$} & \multirow{3}{*}{$\begin{array}{l}\text { Behn, } \\
\text { Carcello, } \\
\text { Hermanson, } \\
\text { and } \\
\text { Hermanson } \\
\text { (1999); } \\
\text { Beattie, } \\
\text { Brandt, and } \\
\text { Fearnley } \\
\text { (1999); } \\
\text { Fatima, } \\
\text { Kami, and } \\
\text { Zaimah } \\
\text { (2014) }\end{array}$} \\
\hline & Independence 2 & \multicolumn{3}{|c|}{$\begin{array}{l}\text { Auditors do not have any perceptions or attitudes } \\
\text { that harms objectivity and honesty during the } \\
\text { audit process }\end{array}$} & \\
\hline & Independence 3 & \multicolumn{3}{|c|}{$\begin{array}{l}\text { Auditors consider and maintain "professional } \\
\text { skepticism" throughout the audit process }\end{array}$} & \\
\hline \multicolumn{6}{|c|}{ Note: $\left({ }^{*}\right)$ The article developed a new scale suitable for the Vietnamese context. } \\
\hline Experts & & Auditor & Audit firm & $\begin{array}{l}\text { Association of certified } \\
\text { public accountants }\end{array}$ & University \\
\hline $\begin{array}{l}\text { Expert } 1 \\
\text { Expert } 2 \\
\text { Expert } 3 \\
\text { Expert } 4 \\
\text { Expert } 6 \\
\text { Expert } 7 \\
\text { Expert } 9 \\
\text { Expert } 10\end{array}$ & & \multicolumn{4}{|c|}{ Training, updating knowledge } \\
\hline $\begin{array}{l}\text { Expert } 1 \\
\text { Expert } 6 \\
\text { Expert } 7 \\
\text { Expert } 9\end{array}$ & & \multicolumn{3}{|c|}{ Competitive environment } & \\
\hline $\begin{array}{l}\text { Expert } 6 \\
\text { Expert } 7 \\
\text { Expert } 8 \\
\text { Expert } 10\end{array}$ & & \multicolumn{2}{|c|}{ Auditing technology } & & \\
\hline $\begin{array}{l}\text { Expert } 6 \\
\text { Expert } 7\end{array}$ & & & Manage & & \\
\hline $\begin{array}{l}\text { Expert } 1 \\
\text { Expert } 2 \\
\text { Expert } 6 \\
\text { Expert } 7 \\
\text { Expert } 10\end{array}$ & & & Check, mon & & \\
\hline
\end{tabular}

